\section{Open 2 access}

DOI: $10.25040 /$ ntsh2020.02.14

Для листування:

Служба психіатрії 116A, VANEOHS, 10701

Східний бул., Клівленд, Огайо 44106

E-пошта: gxj5@case.edu

Стаття надійшла: 11.06.2020

Прийнята до друку: 12.07.2020

Опублікована онлайн: 27.09.2020

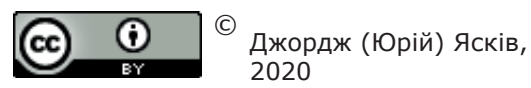

\section{ORCID IDs}

George Jaskiw

https://orcid.org/0000-0002-6544-4142

Конфлікт інтересів: Автори декларують, що немає конфлікту інтересів.

Фінансування: Підготовка цього огляду не потребувала фінансування.

Дозвіл біоетики: Для даного огляду не потрібний.

того, як його розпад заблоковано, введення дофаміну чи його вихідного продукту L-ДОФА може підвищити кров'яний тиск у тварин. Дофамін був біоактивним. Повернувшись до Відня в 1958 році, молодий науковець почав досліджувати дофамін у мозку. Обізнаний із хворобою Паркінсона й заінтригований висновками Арвіда Карлссона про те, що L-ДОФА може протидіяти акінезії щура, що отримав резерпін, доктор Горникевич почав підозрювати, що брак дофаміну запускав рухові симптоми хвороби Паркінсона. Він розробив нові методики, застосував їх для вивчення мозку після смерті, а також продемонстрував, що хвороба Паркінсона пов'язана з браком дофаміну в базальних ядрах. Невдовзі після цього він і Вольтер Біркмаєр спостерігали, як внутрішньовенне введення L-ДОФА могло пробудити німих і нерухомих пацієнтів із хворобою Паркінсона. Вперше хімічна речовина була причетна до складного розладу мозку, а також могла використовуватися для лікування. Це одне з доленосних відкриттів у нейрофармакології. До сьогодні L-ДОФА залишається основним елементом у лікуванні хвороби Паркінсона.

Протягом півстоліття доктор Горникевич продовжував свою роботу, щедро пропонував наставництво та створював мозкові банки у Відні, а також у Торонто (Канада), де працював упродовж багатьох років. Отримав численні нагороди, був номінований на Нобелівську премію з медицини, проте не отримав ії через рішення, яке було доволі суперечливим. Він назавжди залишиться яскравою зіркою в історії нейрофармакології.

Ключові слова: Олег Горникевич, нейронауки, хвороба Паркінсона, L-ДОФА. 


\title{
The firmament of neuroscience loses a shining star (in memoriam Oleh Hornykiewicz)
}

\author{
George Jaskiw \\ Case Western Reserve University, Cleveland, United States
}

Oleh Hornykiewicz, one of the most accomplished neuropharmacologists of the 20th century passed away on May 26, 2020 at the age of 93. In 1939, Oleh's father, a Ukrainian Catholic priest, fled with his young family from Soviet-occupied Ukraine and settled in Vienna. During his medical studies, Oleh became fascinated by pharmacology and in 1956 was awarded a fellowship to Oxford University (U.K.) where he worked with Dr. Hermann Blaschko, a pioneer in the study of enzymes of catecholamine synthesis and metabolism. At that time, it was still thought that dopamine was merely an intermediate in the synthesis of norepinephrine.

Dr. Hornykiewicz demonstrated that even after its breakdown had been blocked, administration of dopamine or its precursor L-DOPA could elevate blood pressure in animal models. Dopamine was bioactive per se. Upon his return to Vienna in 1958, the young scientist began studying dopamine in the brain. Familiar with Parkinson's Disease and intrigued by Arvid Carlsson's finding that L-DOPA could counteract the akinesia of the reserpenized rat, Dr. Hornyckiewicz began to suspect that a dopamine deficiency mediated the motor symptoms of Parkinson's disease. He developed new techniques, applied these to the study of postmortem brains, and demonstrated that Parkinson's disease was associated with a dopamine deficiency in the basal ganglia. Shortly afterwards, he and Walter Birkmeyer observed how the intravenous administration of L-DOPA could awaken mute and akinetic patients with Parkinson's disease. For the first time, a discreet chemical was both implicated in a complex brain disorder and could be used as a treatment. This stands as one of the seminal discoveries in neuropharmacology. To this day, L-DOPA remains a mainstay in the treatment of Parkinson's disease.

Over the following half-century Dr. Hornykiewicz continued his own work, generously mentored others and established brain banks in Vienna as well as in Toronto, Canada where he worked for many years. He received numerous awards, and was nominated for but not awarded the Nobel Prize in Medicine, in a decision that has remained controversial. He will remain forever, a brilliant star in the history of neuropharmacology.

Key words: Oleh Hornykiewicz, neurosciences, Parkinson's Disease, L-DOPA.

Cite this article as: Jaskiw G. The firmament of neuroscience loses a shining star (in memoriam Oleh Hornykiewicz). Proc Shevchenko Sci Soc Med Sci [Internet]. 2020;62(2):104-107. 
Праці НТШ Медичні науки

2020, Том 62, № 2 ISSN 2708-8634 (print)

Актуально

Двадцять шостого травня 2020 року в місті Відні упокоївся в Бозі Олег Горникевич один із найвидатніших науковців фармакологів XX століття в галузі нейронаук. Оцінити його вклад можна, враховуючи історію дослідження катехоламінів і синдром Паркінсона.

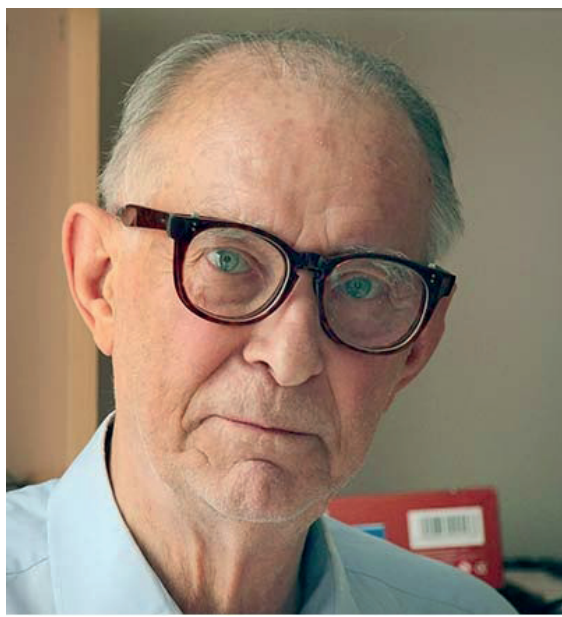

Рис. 1. Олег Горникевич (1926-2020).

У першій половині IX століття англійський лікар Джеймс Паркінсон описав шість припадків так званого paralysis agitans. Часто недуга починалася з тремтіння, а відтак наставали ненормальна хода, м'язова слабкість, параліч, а далі - інші симптоми та смерть. Недуга жорстоко прогресувала, а людина, як описували, поволі застигала, поволі кам'яніла, але часто усвідомлювала свою ситуацію. На початку XX століття лікарі почали застосовувати антихолінергічні препарати та навіть нейрохірургію, утім ефекти часто були мінімальними та завжди короткотривалими. На щастя, нейронаука поволі розвивалася. Фрідріх Луві у 1912 році описав мікроскопічні тіла в мозку тих, хто помер від недуги. Костянтин Третьяков у 1919 році дослідив, що саме substantia nigra в мозку виявляє найзначніші невропатологічні зміни.

Вже на початку XX століття було доведено, що в тілі $\epsilon$ адреналін і норадреналін, які мають надзвичайно важливу дію в таких процесах, як регуляція кров'яного тиску або швидкість серцевого ритму, особливо коли організм стикається зі стресом. Їх класифікували на базі хімічної структури та зачислили до спільної групи катехоламінів. Було також доведено, що катехоламіни можуть діяти як нейромедіатори. 3'ясувалося, що $є$ ще
Proc Shevchenko Sci Soc Med Sci www.mspsss.org.ua ISSN 2708-8642 (online) 2020, Vol. 62,

Current news

третій катехоламін, так званий дофамін, попередник норадреналіну. У деяких клітинах його рівень був не нижчий, ніж рівень інших катехоламінів. Герман Блашко, науковець Оксфордського університету, припускав, що дофамін може мати своєрідну дію, незалежну від норадреналіну. Дослідити це випало молодому науковцеві Олегу Горникевичу.

Олег народився в 1926 році в селі Сихів поблизу Львова. Був наймолодшим із трьох синів. Батько був третім із покоління греко-католицьким священиком. 3 приходом радянської влади (1939) отця Горникевича звільнили 3 вчительської роботи, і родина разом із 13-річним Олегом вимушена була покинути рідну землю. Вони опинилися у Відні, де отець Горникевич став парохом української парафії. Олег, досконало опанувавши раніше незнайому німецьку мову, продовжував навчання. Під час вивчення медицини зацікавився фармакологією. Тому після здобуття диплома лікаря Віденського університету в 1951 році долучився до кафедри фармакології. 3 огляду на наукові здібності професори кафедри рекомендували йому податися на стипендію для подальшої наукової праці у Великій Британії. Отож, восени 1956 року Олег Горникевич почав працювати в лабораторії Блашка.

Він швидко довів на морській свинці, що і дофамін, і його попередник L-ДОФА, діють на кров'яний тиск незалежно від норадреналіну, а отже, заслуговують на подальше обстеження. Коли Катлін Монтагю довела, що дофамін $\epsilon$ в мозку різних тварин і людей, то Олег, який уже в 1958 році повернувся до Відня, почав досліджувати функції церебрального дофаміну. Спершу йому потрібно було винайти нові методи аналізу рівня катехоламінів у мозку. Арвід Карлссон помітив, що L-ДОФА може протидіяти акінезії, зумовленій резерпіном у лабораторних тварин. Ця акінезія дуже нагадувала ненормальну поставу синдрому Паркінсона. Резерпін також викликав у людей тремтіння та ненормальну поставу. До того ж з'ясувалося, що найвищі рівні дофаміну в мозку були в базальних ядрах. I тут, як згадував Олег Горникевич, йому наче спала пелена з очей, і зрозумів можливий зв'язок між дофаміном у мозку та синдромом Паркінсона.

Він завзято взявся до праці й почав разом із колегами вимірювати рівні катехоламінів 
у різних частинах мозку людей: тих, які не мали неврологічних проблем, і тих, які померли від хвороби Паркінсона. Це нелегка праця. Почали дослідження навесні 1959 року, а вже влітку 1960 року з'явилися незаперечні докази. Рівні дофаміну у хвостатому ядрі та корі були нижчі в мозку, ураженому розладом Паркінсона. Уперше в історії нейронауки неврологічний синдром був пов'язаний 3 однією хімічною речовиною в одній частині мозку. Олег відразу почав випробовувати попередника L-ДОФА в клінічних дослідженнях. Він спонукав до цього колегу Вольтера Біркмаєра, який працював у лікарні, де було багато хронічних випадків хвороби Паркінсона. У липні 1961 року Біркмаєр ввів L-ДОФА першим пацієнтам і, вражений ефектом, викликав Олега. Обидва спостерігали чудо фармакології. Одна доза L-ДОФА значно або цілковито усунула акінезію. Пацієнти, які кілька хвилин до того лежали нерухомі в ліжку, могли підвестися, сісти та ходити. До них повернувся голос, і німі заговорили. Для нейронауки це був вражаючий стрибок. Саме з цим в історії й пов'язана праця Горникевича.

Ефекти дожильного L-ДОФА були короткотривалими. Іншим науковцям довелося знайти формулювання ліків, які діяли довше. Сьогодні знаємо, що в разі синдрому Паркінсона $є$ багато інших хімічних речовин, крім дофаміну. Однак ліків, які припиняють розвиток хвороби, немає. Все ж таки, допаміметики, а саме препарати L-ДОФА вже понад півстоліття значно полегшують життя пацієнтів. Це завдяки док- тору Горникевичу. Зрозуміло, що його праця після цього не закінчилася. Протягом наступного півстоліття він інтенсивно продовжував досліджувати дофамін, синдром Паркінсона, інші неврологічні недуги та хімічні речовини. Він майже двадцять років очолював відділ психофармакології Університету Торонто. У 1976 році частково повернувся до Відня (працював на двох континентах). У Торонто він заснував банк мозку й був його директором аж до пенсії. Професор Горникевич отримав більше престижних наукових нагород і почестей, ніж можемо охопити, зокрема нагороду Вольфаі, нагороду ім. Людвіґа Вітґенштайна та нагороду Фундації Варен Алперт.

Варто наголосити, що у 2000 році доктор Горникевич був номінований на Нобелівську премію з медицини або фізіології. Нагороду того року розділили три заслужені науковці нейронауки, але доктора Горникевича серед них не було. Понад 200 нейронауковців написали заяву до Шведської академії, висловлюючи незадоволення та думку про те, що трапилась несправедливість. Сам доктор Горникевич не нарікав. Він продовжував наукову роботу, займався різними зацікавленнями та залишався оптимістом. Він помер на 93 році трудолюбного життя, залишивши в глибокому смутку доньку Марію Гентош у Канаді та синів Миколу, Стефана та Йосифа в Австрії.

Світ, нейронаука та ми, український народ, прощаємося з унікальною людиною. Вічная пам'ять!

\section{Література / References}

1. Roberts Sam. (June 15, 2020). Oleh Hornykiewicz, 93, a Pharmacologist Who Discovered a Treatment for Parkinson's. Section A, Page 20. The New York Times. https://www.nytimes.com/2020/06/12/ science/oleh-hornykiewicz-who-discovered-parkinsons-treatment-dies-at-93.html

2. Heidt Amanda. (June 18, 2020). Oleh Hornykiewicz, Who Pioneered Treatment for Parkinson's, Dies. The New York Times. https://www.the-scientist.com/news-opinion/oleh-hornykiewicz-who-pioneeredtreatment-for-parkinsons-dies-67645

3. Sitte Harald, Willeit Matthäus. 2017 Jan. Introduction to the Special Issue on dopamine celebrating the 90th birthday of Oleh Hornykiewicz. Pub Med. doi: 10.1111/ejn.13502

4. Raiput A.H. (April 01, 2001). An open letter to the Committee on The Nobel Prize in Medicine. Parkinsonism \& Related Disorders. Vol.7, Issue 2. P149-155. doi: https://doi.org/10.1016/S1353-8020(00)00082-1

5. Lees Andrew J., Tolosa Eduardo., Olanow C Warren. (2015 Jan). Four pioneers of L-dopa treatment: Arvid Carlsson, Oleh Hornykiewicz, George Cotzias, and Melvin Yahr. Pub Med. 30(1):19-36. doi: 10.1002/ mds. 26120

6. Pifl Christian, Sperk Günther. (2006 Oct.) Current topics in brain dopamine research: a tribute to Professor Oleh Hornykiewicz. Pub Med. 118(19-20):563-5. doi: 10.1007/s00508-006-0719-6

7. Sommer Barbara W. (February 9, 2007). Interview with Oleh Hornykiewicz. The Movement Disorder Society Oral History Project. Doi: http://www.movementdisorders.org/MDS-Files1/PDFs/hornykiewicz. pdf 